\title{
The Freedom of Navigation in the South China Sea: An Ideal or a Reality?*
}

\author{
Zewei Yang \\ Law School, Wuhan University, Wuhan, China. \\ Email: yangzewei@hotmail.com,fxyyzw@whu.edu.cn \\ Received May $11^{\text {th }}$, 2012; revised June $13^{\text {th }}$, 2012; accepted June $25^{\text {th }}, 2012$
}

\begin{abstract}
The freedom of navigation in the South China Sea has drawn an extensive international concern in recent years. The main reasons leading to skepticism are the disputes in the South China Sea over islands sovereignty and maritime delimitation, extra-regional state's intervention, and some ASEAN member states' wish to countervail China with the help of extra-regional states. In fact there is no problem at all with the freedom of navigation in the South China Sea: on one hand, there are legal regimes to ensure all states' freedom of navigation in different seas according to United Nations Convention on the Law of the Sea; on the other hand, no state impedes the freedom of navigation in the South China Sea. Currently, factors actually affecting the safety of navigation in the South China Sea include piracy, maritime terrorism and so on. Relevant states must take confidence-building measures as well as regional and bilateral cooperation so as to promote the safety of navigation in the region
\end{abstract}

Keywords: Freedom of Navigation; United Nations Convention on the Law of the Sea; The South China Sea

\section{Introduction}

In recent years, some states in different situations raised the freedom of navigation in the South China Sea as a problem, which drew an extensive international concern. The freedom of navigation in the South China Sea is an ideal or a reality? The article will make a thorough analysis about the crux of this problem. The article comprises four sections: the first section focuses on the reasons for the skepticism of the freedom of navigation in the South China Sea, such as the disputes among relevant states, the interventions by extra-regional states, and so on; the second section expounds and proves that there is no problem at all with the freedom of navigation in the region, because, on one hand, there are legal regimes to ensure all states' freedom of navigation in different seas according to United Nations Convention on the Law of the Sea (UNCLOS); on the other hand, no state impedes the freedom of navigation in the South China Sea; the third section looks into factors actually affecting the safety of navigation in the South China Sea, such as piracy, maritime terrorism and so on; the last section proposes some tentative suggestions for the enhancement of regional and bilateral cooperation in the South China

*This article is a part of the results of the research project-“"Territorial Disputes Settlement Mechanism in International Law-China's Choice" (Project No.: NCET-08-0426), sponsored by the "Program for New Century Excellent Talents”, the Ministry of Education, China.
Sea.

\section{Reasons for the Skepticism of the Freedom of Navigation in the South China Sea}

The skepticism of the freedom of navigation in the South China Sea in recent years is due to the following reasons:

\subsection{Disputes over Islands Sovereignty and Maritime Delimitation [1-3]}

As the first country that has discovered and managed the islands in the South China Sea, China has an indisputable sovereignty over these islands and jurisdiction over waters surrounding these islands [4-6]. With the discovery of huge oil and gas reserves beneath its seabed in the 1960s [7] and the formulation of UNCLOS in 1982, some Southeast Asian states, namely the Philippines, Vietnam, Malaysia and Brunei, have claimed sovereignty rights over some islands and its surrounding waters, later on occupied with troops part or all islands which they claimed. Currently, the disputes over island sovereignty are mainly concentrated in the Nansha Islands (the Spratly Islands), involving seven parties, including China, the Philippines, Vietnam, Malaysia, Indonesia, Brunei and China's Taiwan province; as to maritime delimitation, the exclusive economic zone (EEZ) and continental 
shelf claimed by relevant states have overlapped with China's U-Shape Line demarcating the South China Sea, and caused a huge disputing area. Especially in the southern South China Sea, China's U-Shape Line is overlapping with the EEZ claimed by the Philippines, Vietnam, Malaysia, and Brunei, and overlapping with Indonesia's claims to the EEZ and continental shelf in the northeast of Natuna Islands. Therefore China needs to negotiate with Vietnam, the Philippines, Malaysia, Indonesia and Brunei to solve the disputes over maritime delimitation. No doubt that the disputes over island sovereignty and maritime delimitation in the South China Sea has become the most complex disputes involving more countries than any other disputes in the world. The escalating disputes increase the risk of more contradictions and conflicts, thus threatening the safety of maritime navigation [8].

\subsection{Extra-Regional State's Interventions}

Intervention by extra-regional states, such as the USA, Japan and India, have become the important factor influencing its development, and in consequence led to the increasing complexity, persistency and internationalizetion of the South China Sea issue.

1) The United States of America. During the Cold War, due to its need to fight against the Soviet Union, the U.S. took a neutral and non-intervention policy in the South China Sea. However, since the 21st century, the U.S. begins to "seriously concern" [9] of this problem. Especially after its access to the Treaty of Amity and Cooperation in Southeast Asia in July 2009, the U.S. takes up a position of intervention in the South China Sea. For example, Scot Marciel, Deputy Assistant Secretary of State for East Asian and Pacific Affairs, "remain(ed) concerned about tension between China and Vietnam", and pledged to defend U.S. oil companies operating in the region [10]. In 2009, there were two incidents happened between the U.S. and China in the South China Sea ${ }^{1}$ in June 2010, the U.S. Defense Secretary Robert Gates, said in the Ninth Asia Pacific Security Conference, held in Singapore, that the territorial dispute as an "area of growing concern" threatened the freedom of navigation in the sea and economic development. He urged free access to the South China Sea and claimed that Washington was against any action that tried to deter American and other's economic activities in the region [11]. On 23rd July 2010, Hillary Clinton, Secretary of the U.S. State Department, stated at the ASEAN Regional Forum Foreign Ministers' Meeting in Hanoi that America is con-

\footnotetext{
${ }^{1}$ On March 9, 2009, the survey ship USNS Impeccable confronted with Chinese ships in the South China Sea; on June 11, the U.S. destroyer USS John McCain's towed sonar array collided with a Chinese submarine near Subic Bay, the Philippines.
}

cerned about the dispute over the Nansha Islands (the Spratly Islands) and the Xisha Islands (the Paracel Islands) between China and ASEAN member states because it impedes the maritime trade and the access to the international waters against the International Law of the Sea [12]. Furthermore, in a Press Statement issued on 22 July 2011 on the South China Sea, Hillary Clinton also stated: "We also call on all parties to clarify their claims in the South China Sea in terms consistent with customary international law, including as reflected in the Law of the Sea Convention. Consistent with international law, claims to maritime space in the South China Sea should be derived solely from legitimate claims to land features."

2) Japan. As early as the late Qing Dynasty, Japan began to invade the South China Sea by plundering natural resources and seizing islands; until its defeat by the end of World War II that Japan had withdrawn from these islands. When it became a hot spot after the Cold War, Japan then showed its concern about the South China Sea again. To Japan, "it's hard to be neutral" in the dispute over the region; Japan stresses "the stability of waters surrounding these islands in the South China Sea is indispensible of Asian stability" [13]. Japan has strengthened its "non-traditional security" cooperation with ASEAN states, and taken strenuous efforts to infiltrate into the region. In recent years, Japan has participated in military drills and frequently sent warships in the South China Sea in the name of fighting against transnational crimes, such as piracy, drug smuggling, and illegal immigration and so on. It should be noted that recently Japanese Prime Minister Yoshihiko Noda has worked to join hands with the Philippines and Vietnam, both of which have escalating disputes with China. On September 27, 2011, Noda and Philippine President Corazon Aquino III and signed a Japan-Philippines Joint Statement during Aquino III's official working visit to Japan, including the strengthening of maritime cooperation. On October 24, 2011, Noda shook hands with Minister of National Defense of Vietnam General Phung Quang at the Prime Minister's Office and claimed that Japan has the same concern as the states in the South China Sea. He said, "Since we have the same concern, we should make rules and invite China into the discussion. The promotion of observance of rules should be a task fulfilled by cooperation of all states in the region [14]."

3) India. India initiated the "Look East" Policy in 1991, marked its strategic shift that boosts its economic reform through economic cooperation with Southeast Asian states, and at the same time expands its strategic space in the Asia-Pacific region. In April 2000, India Defense Minister George Fernandes said India's sphere of interest

${ }^{2}$ Available at http://www.state.gov/secretary/rm/2011/07/168989.htm 
is extending "from the North of the Arabian Sea to the South China Sea" [15]. After the "9·11" accident, India has sped up its pace of the "Look East" policy. For example, India joined Treaty of Amity and Cooperation in Southeast Asia in 2003; India signed ASEAN-India Partnership for Peace, Progress and Shared Prosperity in 2004; the ASEAN-India Free Trade Area (AIFTA) has been built up to promote their all-around political and economic relations in 2005. In recent years Indian military forces entered the South China Sea in the name of joint military drills with some states in the region. India's breakthrough with its military cooperation with relevant states makes India able to exert its continuous influence on ASEAN states, not only frequently holding bilateral or multilateral military drills, but also reaching agreements, covering military cooperation, piracy, weapons purchasing, information exchange, military training, regular high-level military contacts and so on.

\subsection{Some ASEAN Member States' Wish to Countervail China with the Help of Extra-Regional States}

Some ASEAN member states' strategy is to invite extraregional states and "internationalize" the dispute over the South China Sea, thus arousing international concern. Some even claim that they will submit the dispute to the United Nations. They believe that "the most important is to attract international attention; and at the same time, to expect the advent of the day of internationalizing the dispute over the South China Sea [16].”

These states are anxious about China's development and worry about its possible military threat to them in the future. Therefore, they wish to countervail powerful China's action in the region with the help of the U.S. and Japan. That's why ASEAN, while building up their strength and a united policy against China, welcomes the U.S. military presence in the Asia-Pacific region, and has established and developed various cooperative relations in military and defense. The U.S. president Obama's announcement of its return to Asia in 2009 was welcomed and responded positively by ASEAN states. For example, the Philippines government explicitly expressed that Mutual Defense Treaty between the Republic of Philippines and the $U$. $S$ would be applied to the dispute over the Nansha Islands (the Spratly Islands). Vietnam has been trying to build a mutual defense relationship with the U.S., with a purpose to constraint China's action in the area, by renting its Cam Ranh Bay to the U.S. Pacific fleet. Besides, ASEAN hopes that Japan can play a more important and constructive role in the regional political, economic and security affairs, thus balancing between the U.S. and China.

\section{There Is No Problem with the Freedom of Navigation in the South China Sea at All}

\subsection{United Nations Convention on the Law of the Sea ${ }^{3}$}

The South China Sea is a "semi-enclosed sea", "entirely or primarily of the territorial seas and exclusive economic zones of two or more coastal States"4 (Article 122). Therefore, according to the stipulation of Article 17, "ships of all states enjoy the right of innocent passage through the territorial sea". As to the right of navigation in the EEZ, there is clear statements in Article 58 as well, "In the exclusive economic zone, all States, whether coastal or land-locked, enjoy, subject to the relevant provisions of this Convention, the freedoms referred to in article 87 of navigation and overflight and of the laying of submarine cables and pipelines, and other internationally lawful uses of the sea related to these freedoms, such as those associated with the operation of ships, aircraft and submarine cables and pipelines, and compatible with the other provisions of this Convention.”

Besides, given the fact that the South China Sea is the traffic artery connecting the Pacific Ocean and the Indian Ocean [8], nearly all airlines or shipping routes through the South China Sea must go through the Nansha Islands (the Spratly Islands), with numerous islands and reefs spreading throughout international sea lanes. For these reasons, in accordance with the spirit of "innocent passage” (Article 45), "straits used for international navigation" (Article 34) and "right of archipelagic sea lanes passage" (Article 53), states must be given the right of transit passage in order to ensure freedom of navigation and the openness of sea lanes.

\subsection{No State Impedes the Freedom of Navigation in the South China Sea}

1) China's constant position. The South China Sea is an important maritime waterway, and China always respects the freedom of navigation and overflight in the South China Sea as provided for by the universally recognized principles of international law [17]. In response to concerns expressed by the U. S State Department in May, 1995, the spokesperson of the Ministry of Foreign Affairs of China Chen Jian stated that China while safeguarding its sovereignty over the Nansha Islands, and its marine rights and interests, China will fulfill its duty of guaranteeing freedom of navigation and overflight in the

${ }^{3} 1833$ UNTS 397, adopted in Montego Bay, Jamaica, on 10 December 1982, entered into force on 16 November 1994.

${ }^{4}$ Article 122, "the 1982 UN Convention on the Law of the Sea," "enclosed or semi-enclosed sea” means a gulf, basin or sea surrounded by two or more States and connected to another sea or the ocean by a narrow outlet or consisting entirely or primarily of the territorial seas and exclusive economic zones of two or more coastal States. 
South China Sea according to international law [18]. Furthermore, Yang Jiechi, the Chinese Foreign Minister has made an objective evaluation of this issue at the ASEAN Regional Forum Foreign Ministers' Meeting in Hanoi in July 2010, and pointed out that the dispute over the South China Sea is a dispute over territorial sovereignty and maritime interests between China and a few ASEAN member states, not between China and ASEAN [19]. China reiterated this position as recently as 29 September 2011. Hong Lei, the spokesperson of the Ministry of Foreign Affairs of China, spoke at the regular press conference, stated that “China's position on the South China Sea is clear and consistent. China safeguards its sovereignty and maritime rights and interests in the South China Sea, which does not affect freedom of navigation in the South China Sea enjoyed by countries according to international law. In fact, there is no problem with the freedom and safety of navigation in the South China Sea; all countries within the region and out of the region are beneficiaries of free and safe navigation in the South China Sea, which is also the common view of all relevant states [20]." In fact, 70,000 vessels passed peacefully through the South China Sea every year [21].

2) Attitudes of other relevant states. So far, other relevant states have expressed no explicit objection to the freedom of navigation in the South China Sea. It should be noted that China and the ASEAN Member States have signed the Declaration on the Conduct of Parties in the South China Sea (DOC) in November 2002. "The Parties reaffirm their respect for and commitment to the freedom of navigation and overflight in the South China Sea as provided for by the universally recognized principles of international law, including the 1982 UN Convention on the Law of the Sea". In July 2011, the China-ASEAN foreign ministers' meeting have also adopted Guidelines for the Implementation of the DOC, "Reaffirming that the DOC is a milestone document signed between the ASEAN Member States and China, embodying their collective commitment to promoting peace, stability and mutual trust and to ensuring the peaceful resolution of disputes in the South China Sea"; "The decision to implement concrete measures or activities of the DOC should be based on consensus among parties concerned, and lead to the eventual realization of a Code of Conduct". ${ }^{5}$

\subsection{The Freedom of Navigation in the South China Sea is Not an Absolute Right}

The freedom of navigation in the South China Sea is not an absolute freedom without any restriction; instead each state must perform certain international obligations while

\footnotetext{
${ }^{5}$ Preface and Article 6, Guidelines for the Implementation of the DOC.
}

enjoying free navigation. In other words, the navigation through the territorial sea under the jurisdiction of a state should be a peaceful navigation and comply with the rights and duties of the coastal state as well as respect their security interests and sovereign rights. These rights and duties have stipulated in Article 21 and Article 58, United Nations Convention on the Law of the Sea, which reads:

Foreign ships exercising the right of innocent passage through the territorial sea shall comply with all such laws and regulations and all generally accepted international regulations relating to the prevention of collisions at sea. (Article 21)

In exercising their rights and performing their duties under this Convention in the exclusive economic zone, States shall have due regard to the rights and duties of the coastal State and shall comply with the laws and regulations adopted by the coastal State in accordance with the provisions of this Convention and other rules of international law in so far as they are not incompatible with this Part. (Article 58)

Besides, there is no absolute freedom in modern maritime legal regimes. Even in high seas, each ship in exercising its freedom of navigation must abide by international navigation regulations according to international law and generally acknowledged international customs, for example, "collision regulation"; each must respect other's freedom of navigation; at the same time all ships are under the related international obligations, such as preventing, reducing and controlling marine pollution, protect and preserve marine environment, keeping safe navigation and observing maritime traffic rules and so on.

Guidelines for Navigation and Overflight in the Exclusive Economic Zone (EEZ), developed by the EEZ Group 21 composed by senior officials and analysts primarily from countries of the Asia-Pacific region from 20022005, stated explicitly:

III a) While exercising the freedoms of navigation and overflight in an EEZ, States should avoid activities that unreasonably prejudice the peace, good order or security of the coastal state.

b) States' exercise of the freedoms of navigation and overflight should not interfere with or endanger the rights of the coastal State to protect and manage its own resources and their environment.

c) The exercise by other States of the freedoms of navigation and overflight should not interfere with the rights of the coastal State with regard to its establishment and use of artificial islands, installations and structures in its EEZ.

V b). Ships and aircraft of a State undertaking military activities in the EEZ of another State have the obligation 
to use the ocean for peaceful purposes only, and to refrain from the threat or use of force, or provocative acts, such as stimulating or exciting the defensive systems of the coastal State; collecting information to support the use of force against the coastal State; or establishing a "sea base" within another State's EEZ without its consent. The user State should have due regard for the rights of others to use the sea including the coastal State and comply with its obligations under international law [22].

\section{Factors Actually Affecting the Safety of Navigation in the South China Sea}

There are three key factors now actually affecting the safety of navigation in the South China Sea:

\subsection{Increasingly Rampant Piracy}

The South China Sea is one of the areas that are famous for the most rampant piracy, and the Strait of Malacca in its southwest was regarded as the most dangerous waters for pirate activities [23] in the 1990s. However, with the joint maritime patrol by Malaysia, Singapore and Indonesia in combating against piracy in Malacca Strait, the main battlefield for anti-piracy has moved to the South China Sea, especially the waters surrounded by Hong Kong, Luzon Island and Hainan Island [24]. In the 21st century, piracy seems to have run wilder given the fact that pirates have attacked more and more fishing and merchant ships in the region, which makes piracy the biggest threat to the safety of navigation in the South China Sea.

Pirates in the South China Sea have advanced navigational equipments and weapons. Fishing boats from China's Hainan Province have been attacked by pirates frequently. Statistics shows, from 2000-2006, the fishing boats from Qionghai Prefecture, Hainan Province, while operating in the region, had experienced 88 robberies, 144 fishing boats and more than 400 fishermen had been attacked, including 5 murdered and 4 wounded, which caused a direct economic loss of more than RMB 70 million [25]. Piracy and Armed Robbery Against Ships Report-Annual Report 2008, made by International Maritime Bureau, indicates that there are 293 actual and attempted attacks in the world in 2008, of which 75 attacks happened in the Southeast Asia waters and the South China Sea, including 11 in Vietnam and Cambodia, 28 in Indonesia, 6 in Malacca Strait, 12 in Malaysia, 7 in the Philippines, 6 in Singapore, and 5 in the South China Sea [26]. Recently, piracy in the South China Sea has been in an increasing tendency, for example, in February, 2010, pirates attacked Singapore-registered tugboat "Topniche7", and two months later, pirates robbed a Singapore flagged tug in Malaysian waters [16].

\subsection{Terrorist Activities}

Besides the rampant piracy, maritime terrorist activity is another increasingly serious threat to the safety of navigation in the South China Sea. After the "9.11" accident, terrorist activities in Southeast Asia have been happening with increasing frequency, states such as Indonesia, the Philippines and Malaysia have become the high-risk areas of terrorist attacks, where terrorist organizations, such as Moro Islamic Liberation Front (MILF), Abu Sayyaf Group (ASG), Free Aceh. Movement (GAM) and Jemaah Islamiya (JI), are much active $[27,28]$.

"What international society concerns most is that terrorist organizations and members may engage in maritime terrorist attacks to cut off the maritime traffic in the region, hence making terrorist activities a huge potential threat to the safety of navigation in the South China Sea [29].” The International Maritime Bureau indicates that "Terrorist groups including al Qaeda attempt to use a boat loaded with explosives to attack oil tankers and merchant ships, this type of maritime terrorist attack has become a new trend of maritime robbery [30]." "The United States of America also regards Southeast Asian Muslim extremist as the potential threat to commercial navigation, because terrorists may hi-jack a liquefied natural gas tanker and turn it into a floating bomb to destroy ports. When attacks become more and more serious, ship owners and captains will probably choose other safe waters instead of the South China Sea [31].”

\subsection{Activities of Foreign Armed Ships}

Besides threats from piracy and maritime terrorism to the safety in the South China Sea, foreign armed ships have frequently attacked Chinese fishing boats. In June 2009, 8 fishing boats operating within China's U-Shape Line suddenly lose communication; later investigation showed that 3 armed Indonesian ships visited with force and detained all 75 fishermen in the 8 fishing boats. According to statistics from Bureau of Marine and Fishery of Lingao County, Hainan Province, more than half of fishing boats from Lingao County have once been stolen or robbed of fishing nets, which leads to a direct loss of more than RMB 10 million [32].

Against the backdrop of escalating dispute over the South China Sea, relevant states frequently make Chinese fishermen the first target of attack, detaining, confiscating, shooting and killing against law and humanity. Statistics from Hainan Province Public Security Border Battalion shows that from 2003-2008 fishing boats, registered in Hainan Province, while operating in the South China Sea, have been detained by neighboring states for 75 times, detaining 75 boats and 738 fishermen, with a total direct loss of more than RMB 35 million [32]. 
Even worse, it is possible for piracy, terrorism and organized crime to be collaborated in the South China Sea. Piracy will provide finance for terrorists to purchase weapons; organized crime such as maritime smuggling will provide terrorists with weapons and explosives; and terrorist groups will provide special skills for pirates and criminal organizations to evade law enforcement agency's pursuit and arrest. The collaboration will benefit all of them. If it permits, terrorism base and hiding-place could be a shelter for pirates and criminal organizations, the latter in turn covering terrorist activities. Moreover, their trans-boundary activities and evasion through high seas have made it extremely difficult for law enforcement agency to catch them.

\section{Some Suggestions}

In order to meet the challenges from piracy and maritime terrorism, states around the South China Sea, the U.S. and Japan have been attempting to establish cooperation mechanisms to maintain the safety of navigation in the region. For example, some ASEAN member states have participated joint patrol measures-Five Power Defense Arrangement (FPDA) and Eye in the Sky; the U.S. has held large-scale joint maritime military drills with Thailand, the Philippines, Indonesia, Malaysia and Singapore; under the cover of anti-terrorism and return to Asia strategy, the U.S. has strengthened its military influence in the region.

Japan has been also taken efforts to build and participate security cooperation mechanism in the South China Sea, and provided aids to Southeast Asian states' maritime safety. Regional Cooperation Agreement on Combating Piracy and Armed Robbery in Asia, initiated by Japan in 2004, has been attached great importance by ASEAN states, for example Singapore, and become one of the most influential multilateral mechanisms for maritime non-traditional safety in the South China Sea. States in the region from now on should enhance mutual trust as well as bilateral and regional cooperation, so as to secure the safety of navigation in the South China Sea.

\subsection{The Confidence-Building Measures}

The Guidelines for the Implementation of the DOC, adopted by the China-ASEAN Foreign Ministers' Meeting in July 2011, points out that "Initial activities to be undertaken under the ambit of the DOC should be confidence-building measures”, Therefore, in order to reduce the risk in the safety of navigation in the South China Sea, the relevant states must take confidence-building measures, or draft safety codes for navigation, for example, "Agreement of Preventing Maritime Accidents in the

${ }^{6}$ Article 5: Guidelines for the Implementation of the DOC.
South China Sea", which can cover navigation under, in and above the sea, maritime exploration and research, naval drills, transportation of petrol and gas, cooperation in anti-piracy and anti-terrorism, fishery administration, protection of marine environment, administration of transportation of dangerous radioactive materials, and so on. It will help to secure a regular negotiation between related states on maritime safety, prevent marine and air collisions, as well as reduce the risk of accidents caused by normal activities. "Agreement of Preventing Maritime Accidents in the South China Sea" may start from bilateral agreements, and extend gradually to multilateral.

\subsection{The Bilateral and Regional Cooperation}

The effective way to maintain the safety of navigation in the South China Sea is through cooperation of neighboring states. So, China can negotiate with each member state of ASEAN, especially with Vietnam, Malaysia and the Philippines, and establish a bilateral maritime safety cooperation mechanism. Through holding bilateral activities, such as joint military drills, marine rescue operation, mutual warships visit and so on, China should promote bilateral military cooperation, build confidence between China and ASEAN states, and eliminate their doubts, thereby creating a better condition for the safety of navigation in the South China Sea.

Furthermore, the Declaration on the Conduct of Parties in the South China Sea (DOC) has set up five areas for cooperation, namely, marine environmental protection, marine scientific research, safety of navigation and communication at sea, search and rescue operation, and combating transnational crime, including but not limited to trafficking in illicit drugs, piracy and armed robbery at sea, and illegal traffic in arms, ${ }^{7}$ which should be the priority in regional cooperation among relevant states. ${ }^{8}$

In conclusion, the freedom and safety of navigation in the South China Sea are in conformity with the interest of all states within and out of the region. Extra-regional states are most concerned with the freedom of navigation in the region. The U.S. and Japan are seriously concerned with free and safe passage along vital sea lanes and air lanes in the region. The former U.S. State Department spokesman James P. Rubin once said, "The freedom of navigation is America's fundamental interest. It is crucial,

\footnotetext{
${ }^{7}$ Article 6: The Declaration on the Conduct of Parties in the South China Sea.

${ }^{8}$ Because the South China Sea is a "semi-enclosed sea", article 123 of UNCLOS impose a general obligation on States bordering a semienclosed sea to cooperate with each other in the exercise of their rights and in the performance of their obligations under the Convention. In particular, these States are obliged to endeavour, directly or through an appropriate regional organization, to coordinate their activities in three areas: (a) the management, conservation, exploration and exploitation of the living resources; (b) the protection and preservation of the marine environment; and (c) marine scientific research.
} 
for the peace and prosperity of the Asia-Pacific region including the U.S., to ensure all ships and planes to pass without obstacle through the South China Sea [33].” In fact, China has announced repeatedly that it respects the freedom of navigation of vital sea lanes through the South China Sea; China did not and will never intervene foreign ships going through the region, and there is no indication that China will impede the freedom of navigation. However, the freedom of navigation doesn't mean freedom of military activities in the South China Sea; instead, states exercising their freedom of navigation must be for peaceful purposes only and respect the coastal states’ sovereignty and security interests.

\section{REFERENCES}

[1] D. Rosenberg, Ed., "South China Sea WWW Virtual Library,” 2012. http://www.southchinasea.org/index.html

[2] R. W. Smith, "Maritime Delimitation in the South China Sea: Potentiality and Challenges," Ocean Development \& International Law, Vol. 41, No. 3, 2010, pp. 214-236. doi:10.1080/00908320.2010.499315

[3] C. Schofield and I. Storey, "The South China Sea Dispute Increasing Stakes and Rising Tensions,” The Jamestown Foundation, Washington DC, 2009.

[4] K. Y. Zou, "The Chinese Traditional Maritime Boundary Line in the South China Sea and Its Legal Consequences for the Resolution of the Dispute over the Spratly Islands," International Journal of Marine and Coastal Law, Vol. 14, No. 1, 1999, pp. 27-55.

[5] J. M. Shen, "International Law Rules and Historical Evidences Supporting China's Title to the South China Sea Islands," Hastings International \& Comparative Law Review, Vol. 21, 1997-1998, pp. 1-75.

[6] J. M. Shen, "China's Sovereignty over the South China Sea Islands: A Historical Perspective,” Chinese Journal of International Law, Vol. 1, No. 1, 2002, pp. 94-157. doi:10.1093/oxfordjournals.cjilaw.a000432

[7] C. Schofield, “Dangerous Ground,” In: S. Bateman and R. Emmers, Eds., Security and Politics in the South China Sea, Routledge, London, 2009, pp. 7-25.

[8] R. Beckman, "China, UNCLOS and the South China Sea," Asian Society of International Law Third Biennial Conference, Beijing, 27-28 August 2011, 32 pp.

[9] Y.-H. Song, "The Overall Situation in the South China Sea in the New Millennium: Before and After the September 11 Terrorist Attacks," Ocean Development \& International Law, Vol. 34, No. 3-4, 2003, pp. 229-277.

[10] U. S. Department of State, "Maritime Issues and Sovereignty Disputes in East Asia,” Testimony of Deputy Assistant Secretary Scot Marciel Bureau of East Asian \& Pacific Affairs U. S. Department of State before the Subcommittee on East Asian and Pacific Affairs Committee on Foreign Relations United States Senate, 2009. http://vietnam.usembassy.gov/uploads/images/3VC0_Hw h5_paP5TLrjbLNg/MarcielTestimony090715p.pdf
[11] I. Storey, "Shangri-La Dialogue Highlights Tensions in Sino-U.S. Relations,” China Brief, Vol. 10, No. 13, 24 June 2010.

http://www.jamestown.org/programs/chinabrief/single/?tx _ttnews\%5Btt_news\%5D=36532\&cHash=cbac584235

[12] R. Sutter, "United States and China: Will Positive Relations Endure?” East Asia Forum, 13 September 2010. http://www.eastasiaforum.org/2010/09/13/united-states-a nd-china-will-positive-relations-endure/

[13] R. A. Cossa, "A Pacific Forum CSIC Special Report: Security Implications of Conflict in the South China Sea: Exploring Potential Triggers of Conflict,” 2012. http://www.csic.org/pacfor/opSChinasea.pdf

[14] Financial Times, 30 October 2011. http://www.ft.com/intl/world/asiapacific/china

[15] Z. M. Zheng, "The Influence of Great States in the South China Sea Issue-U. S., Japan, India, Russia and the South China Sea Issue,” World Affairs Press, Beijing, 2010, p. 153.

[16] F. G. Liu and S. C. Wu, Eds., "Report on Situation of the South China Sea Region in 2010,” The Centre of International Relations of Taiwan National Politics University, Taipei, 2011, p. 45.

[17] Z. M. Liu, "The Basic Position of China on the Settlement of Maritime Disputes through Negotiations," China Oceans Law Review, Vol. 3, No. 2, 2005, p. 21.

[18] Statement of the Spokesperson of the Ministry of Foreign Affairs of China Chen Jian, "News Briefing by Chinese Foreign Ministry,” Beijing Review, 8-14 May 1995, p. 22.

[19] China News, 2011. http://www.chinanews.com.cn/gi/2010/07-26/2423966.sh tml

[20] “China’s Foreign Ministry Spokesperson Hong Lei’s Regular Press Conference on September 29, 2011,” 2011. http://www.mfa.gov.cn/chn/gxh/tyb/fyrbt/jzhsl/t863756.h tm

[21] D. H. Paal, "Beware the South China Sea," The Diplomat, 15 July 2011.

http://the-diplomat.com/2011/07/15/beware-the-south-chi na-sea/2/

[22] EEZ Group 21, “Guidelines for Navigation and Overflight in the Exclusive Economic Zone,” Ocean Policy Research Foundation, Tokyo, 2005, pp. 7-9. http://www.sof.or.jp/en/report/index.php\#0509

[23] R. C. Beckman, "Combating Piracy and Armed Robbery against Ships in Southeast Asia: The Way Forward," Ocean Development \& International Law, Vol. 33, No. 3-4, 2002, pp. 317-341. doi:10.1080/00908320290054800

[24] C. Liss, "Maritime Piracy in Southeast Asia," Southeast Asia Affairs 2003, Vol. 2003, 2003, pp. 52-68.

[25] J. M. Li, "The Safety in the South China Sea: Combating against Piracy and Anti-Terror Cooperation," Southeast Asian Affairs, Vol. 16, No. 3, 2008, p. 11.

[26] International Maritime Bureau, "Piracy and Armed Robbery against Ships Report-Annual Report 2008,” 2008, pp. 5-12.

[27] B. Bingley, "Security Interests of the Influencing States: 
The Complexity of Malacca Straits," The Indonesian Quarterly, Vol. 32, No. 4, 2004, pp. 353-383.

[28] A. Tan, “The Persistence of Armed Muslim Rebellion in Southeast Asia: Implications after September 11,” In: D. M. Jones, Ed., Globalization and the New Terror: The Asia Pacific Dimension, Edward Elgar Publishing, Cheltenham, Northampton, 2004, p. 213.

[29] P. H. Cai, "On the Cooperation Mechanism of the Sea Safety in the South China Sea," Contemporary International Relations, Vol. 26, No. 6, 2006, p. 7.

[30] R. C. Beckman, “Combating Piracy and Armed Robbery against Ships in Southeast Asia: The Way Forward," Ocean Development \& International Law, Vol. 33, No. 3-4, 2002, pp. 317-341. doi:10.1080/00908320290054800

[31] J. H. Ho, "The Security of Sea Lanes in Southeast Asia," Asian Survey, Vol. 46, No. 4, 2006, pp. 558-574. doi:10.1525/as.2006.46.4.558

[32] J. Zhang, "The Situation of the Safety of Navigation in the South China Sea and China's Response," Journal of the Yinchuan Municipal Party College of C. P. C., Vol. 10, No. 3, 2010, p. 42.

[33] The Washington Times, 5 January 1999. 